\title{
A Specific Polysaccharide from Mycoplasma mycoides
}

\author{
By S. H. BUTTERY AND P. PLACKETT \\ Division of Animal Health, C.S.I.R.O., Animal Health Research Laboratory, \\ Private Bag No. 1, Parkville, N. 2 Victoria, Australia
}

(Received 2 May 1960)

\section{SUMMARY}

Washed suspensions of Mycoplasma mycoides var. mycoides were found to contain c. $10 \%$ by weight of carbohydrate. The only sugars detected in hydrolysates were galactose and ribose. A galactan was obtained by extraction with warm aqueous phenol. The galactan was separated from ribonucleic acid by ultracentrifugation or by treatment with an ion-exchange resin. The product was rapidly hydrolysed by acid, releasing galactose and $c .4 \%$ of $\mathrm{CHCl}_{3}$-soluble lipid. It formed precipitates with specific antiserum and could be used to sensitize sheep erythrocytes to agglutination by the antiserum. It was not pyrogenic for rabbits and had little in common with the lipopolysaccharides of typical Gram-negative bacteria.

\section{INTRODUCTION}

Little is known of the carbohydrates of the pleuropneumonia-like organisms (PPLO), although Kurotchkin (1937) isolated from Mycoplasma mycoides a serologically active fraction which gave positive Molisch and negative biuret reactions. We report here a study of the strain ('V 5 ') of $M$. mycoides var. mycoides used in this laboratory for the preparation of a vaccine against contagious bovine pleuropneumonia. Our objectives were to identify the component sugars and to examine the organism for the presence of specific polysaccharides. Warm aqueous phenol has been widely used for the extraction of lipopolysaccharides from Gram-negative bacteria (Westphal, Lüderitz \& Bister, 1952). These complex materials are derived from the cell-wall structure and carry the specificity of the somatic antigens. It was of interest to apply this method to one of the Mycoplasma organisms, which lack a cell-wall of the kind found in typical bacteria (Kandler \& Zehender, 1957; Plackett, 1959).

\section{METHODS}

\section{Preparation of washed suspensions}

Mycoplasma mycoides var. mycoides strain 'V 5' was grown in BVF-OS medium (Turner, Campbell \& Dick, 1935). This consists of a pig-stomach digest of beef liver and muscle, buffered at $\mathrm{pH} 7 \cdot 4$ and supplemented with $10 \%(\mathrm{v} / \mathrm{v})$ of ox serum. Five-litre Florence flasks, containing 2-3 1 . medium at $37^{\circ}$, were inoculated with 5-8 ml./l. of a 4-day culture in the same medium. They were rotated during incubation by a device of the kind described by Mitchell (1949), on which two flasks could be rotated simultaneously. The cultures were harvested after $24-28 \mathrm{hr}$. at $37^{\circ}$, when the number of viable particles was $10^{9}-10^{10} / \mathrm{ml}$, and the optical density was still 
increasing. At first the contents of two flasks were pooled and worked up as a single batch. Satisfactory preparations were also obtained from cultures which had been stored at $4^{\circ}$ for up to 3 days, so that the yield from six flasks could be harvested in one operation. Harvesting was done on a steam-driven Sharples Supercentrifuge, the bowl of which was lined with a sheet of plastic material (Rodwell \& Rodwell, 1954). The paste of organisms was removed from the latter with a spatula and resuspended in about $80 \mathrm{ml}$. of $0.2 \mathrm{M}-\mathrm{NaCl}$ at $4^{\circ}$. A large all-glass syringe was a convenient tool for resuspending the sticky paste. The organisms were resedimented at $40,000 \mathrm{~g}$ for $15 \mathrm{~min}$. They were washed once or twice in cold distilled water and were then stored at $-16^{\circ}$ until required.

Total carbohydrate estimations. Two colorimetric procedures were used. The orcinol $+\mathrm{H}_{2} \mathrm{SO}_{4}$ reaction was carried out following, with minor modifications, the directions of Vasseur (1948). The tubes were heated at $80^{\circ}$ for $20 \mathrm{~min}$. and the optical density measured at $500 \mathrm{~m} \mu$. The anthrone reaction was carried out as recommended by Trevelyan \& Harrison (1952). D-galactose, being the only sugar found apart from the nucleic-acid components, was used as the standard for both procedures. Galactose added to washed suspensions was quantitatively recovered by both methods. The galactose equivalents found by the orcinol $+\mathrm{H}_{2} \mathrm{SO}_{4}$ reaction were higher than those by the anthrone method. With orcinol ribose and galactose give approximately the same extinction/mole, but with anthrone ribose gives much less colour. Unless otherwise stated, values for total carbohydrate refer to the galactose equivalent as determined by the anthrone method; they include the contribution from the nucleic acids, which amounted to about $10 \%$ of the total in the case of the unfractionated washed suspensions.

Pentose and deoxypentose. The orcinol $+\mathrm{HCl}$ reagent of Militzer (1946) was used to determine pentose compounds, and the diphenylamine reagent (Dische, 1955) for deoxypentose. The appropriate purine nucleotides or nucleic acids were used as standards. Removal of nucleic acid during purification of the polysaccharide fraction was estimated by measurement of the optical density at $260 \mathrm{~m} \mu$ in $1 \mathrm{~cm}$. silica cuvettes.

Uronic acids. The carbazole test was carried out according to Dische (1947), with glucuronolactone as a reference compound.

Reducing sugars. Neutralized hydrolysates were analysed by the colorimetric procedure of Somogyi (1952). D-galactose was the standard and the heating period was $35 \mathrm{~min}$.

Esterified fatty acids. The hydroxamate reaction was carried out according to Stern \& Shapiro (1953), with recrystallized trimyristin as the standard.

Phosphorus. Total $\mathbf{P}$ was determined by the method of Fiske \& SubbaRow as modified by Chen, Toribara \& Warner (1956) and by Bartlett (1959).

Nitrogen. The procedure recommended by Conway (1947) was followed, except that the $\mathrm{NH}_{3}$ determination was made by Nesslerization.

Periodate oxidations. Periodate consumption was estimated by measurement of the optical density at $290 \mathrm{~m} \mu$ of samples of the reaction mixtures diluted tenfold with $0.05 \mathrm{M}$-sodium acetate buffer $(\mathrm{pH} 4)$. Solutions of sodium metaperiodate and sodium iodate were similarly diluted for use as standards. Formaldehyde was determined by means of the acetylacetone reagent $B$ of Nash (1953) on samples which had been treated with $\mathrm{I}_{2}$ and $\mathrm{Na}_{2} \mathrm{~S}_{2} \mathrm{O}_{3}$ to destroy excess periodate. The reaction 
time was $1 \mathrm{hr}$. at $38^{\circ}$. Some samples were analysed with a chromotropic acid reagent after removal of excess periodate with lead dithionate according to O'Dea \& Gibbons (1953). The unoxidized polysaccharide gave a large blank with this reagent. When correction for the blank was made, or when the samples were treated with sodium arsenite and the formaldehyde separated by distillation, the same values were obtained as with the acetylacetone reagent.

Paper chromatography of sugars. Samples containing large amounts of protein were hydrolysed in sealed tubes with $1 \mathrm{ml} .0 .25 \mathrm{~N}-\mathrm{H}_{2} \mathrm{SO}_{4} / 0.5 \mathrm{mg}$ total carbohydrate. The tubes were heated at $100^{\circ}$ for $18-20 \mathrm{hr}$. After removal of sulphate as $\mathrm{BaSO}_{4}$, incompletely hydrolysed protein was precipitated with ethanol as recommended by Gottschalk \& Ada (1956). The overall recovery of total carbohydrate, determined by the orcinol $+\mathrm{H}_{2} \mathrm{SO}_{4}$ or the anthrone reaction, was $c .80 \%$. Hydrolysates were chromatographed on Whatman no. 1 paper by the descending technique. The following solvent systems were used: water-saturated phenol (in the presence of $\mathrm{NH}_{3}$ and $\mathrm{KCN}$ ), $n$-butanol + pyridine + water $(6: 4: 3), n$-butanol + ethanol + water (52:31:17), $n$-butanol + glacial acetic acid + water (4:1:5), iso-propanol + water $(9: 1)$, and water-saturated $s$-collidine. Reagents used to detect the spots included ammoniacal $\mathrm{AgNO}_{3}$ (Dedonder, 1952), aniline hydrogen phthalate (Cummins \& Harris, 1956), lead tetra-acetate in benzene (Buchanan, Dekker \& Long, 1950) and $\beta$-indolylacetic acid (Heyrovsky, 1956).

Reversed-phase chromatography of long-chain fatty acids. Long-chain fatty acids were chromatographed on disks of Whatman no. 1 paper impregnated with a paraffin fraction (b.p. $200^{\circ}-210^{\circ}$ ) as described by Nowotny, Lüderitz \& Westphal (1958). Dithio-oxamide $(0.03 \%, \mathrm{w} / \mathrm{v})$ in ethanol (Ballance \& Crombie, 1958) was used to detect the positions of the $\mathrm{Cu}^{++}$salts. $\mathrm{OsO}_{4}$ vapour was used to reveal unsaturated acids.

Dry weights. Samples of the washed suspensions of organism were dried in an oven at $100^{\circ}$ overnight. Analytical data for the purified polysaccharide fraction refer to material dried to constant weight in vacuo at $78^{\circ}-80^{\circ}$.

Ultracentrifugation. The Spinco model $\mathbf{L}$ preparative ultracentrifuge was used. The rotors were precooled to $2^{\circ}-4^{\circ}$ and the rotor chamber was refrigerated during runs. The centrifugal fields are those at the centre of the tubes (average radius), and the times do not include acceleration and deceleration periods. Analytical ultracentrifugation was done in the Spinco model E.

\section{RESULTS}

\section{Identification of the component monosaccharides}

The unfractionated suspensions were found to contain total carbohydrate equivalent to $c .10 \%$ of the dry weight. For a series of four batches of organisms the values ranged from $10 \cdot 3$ to $12.8 \mathrm{mg}$. galactose $/ 100 \mathrm{mg}$. dry weight, the mean value being $11 \cdot 2 \mathrm{mg}$. These values include the contribution from the nucleic acids, which was equivalent to about $1 \mathrm{mg}$. galactose $/ 100 \mathrm{mg}$. dry weight. No uronic acid was detected. Only traces of hexosamine-like material are present in suspensions of Mycoplasma mycoides (Plackett, 1959).

When hydrolysates were chromatographed on paper it was found that most of the sugar migrated like galactose in all the solvent systems. Only two other com- 
ponents were detected. The most abundant of these was identified as ribose (see below), presumably derived from ribonucleic acid (RNA). A third very faint spot of high mobility appeared on papers which had been run in the butanol-containing solvents and then developed with the $\mathrm{AgNO}_{3}$ reagent; this was probably glycerol (see below). To confirm the identity of the main component sugar with galactose, a hydrolysate of washed organism was fractionated on a column of cellulose powder (Hough, Jones \& Wadman, 1949). Table 1 shows the recovery of material during processing of the hydrolysate. A portion of the lyophilized residue, containing $5.3 \mathrm{mg}$. pentose and $\mathbf{2 3 . 9} \mathrm{mg}$. galactose (anthrone method, corrected for

\section{Table 1. Recovery of sugars after hydrolysis of washed Mycoplasma organisms}

The washed organism was hydrolysed in $0.25 \mathrm{~N}-\mathrm{H}_{2} \mathrm{SO}_{4}$ for $18-20 \mathrm{hr}$. at $100^{\circ}$.

\begin{tabular}{|c|c|c|}
\hline \multirow[b]{2}{*}{. } & \multicolumn{2}{|c|}{$\begin{array}{l}\text { Total galactose equivalent } \mathrm{mg} . / 360 \mathrm{mg} \\
\text { dry wt. }\end{array}$} \\
\hline & $\underset{\text { reaction }}{\text { Orcinol }+\mathrm{H}_{2} \mathrm{SO}_{4}}$ & $\begin{array}{l}\text { Anthrone } \\
\text { reaction }\end{array}$ \\
\hline Unhydrolysed suspension & $55(100)$ & $40 \cdot 5(100)$ \\
\hline $\begin{array}{l}\text { Hydrolysate after removal } \\
\text { of insoluble residue }\end{array}$ & $48.5(88)$ & $38 \cdot 3(94)$ \\
\hline After precipitation of $\mathrm{BaSO}_{4}$ & $47 \cdot 2(86)$ & $37 \cdot 6(93)$ \\
\hline $\begin{array}{l}\text { Concentrated supernate from } \\
\text { ethanol precipitation }\end{array}$ & $45 \cdot 8(83)$ & $37 \cdot 5(93)$ \\
\hline $\begin{array}{l}\text { After passage through } \\
\text { cation-exchanger IR-120 }\left(\mathrm{H}^{+}\right)\end{array}$ & $44 \cdot 4(81)$ & $36 \cdot 2(89)$ \\
\hline After lyophilization & & $33 \cdot 8(84)$ \\
\hline
\end{tabular}

pentose), was transferred in a small volume of water to the top of a $25 \mathrm{~g}$. column of Whatman Ashless Cellulose powder which had been exhaustively washed with the eluting solvents. Pentose was eluted with acetone + water (95:5 by vol.), and hexose with methanol. The eluates were evaporated to dryness. The residue from the hexose fraction was dissolved in $1.2 \mathrm{ml} .50 \%(\mathrm{v} / \mathrm{v})$ ethanol in water and mixed with $0.035 \mathrm{ml} .10 \%(\mathrm{v} / \mathrm{v})$ acetic acid and $0.04 \mathrm{ml}$. of freshly distilled a-methylphenylhydrazine. After $2 \mathrm{hr}$. at $37^{\circ}$ and $2 \mathrm{hr}$. at $3^{\circ}$ the precipitate was filtered off and recrystallized four times from $30 \%(\mathrm{v} / \mathrm{v})$ ethanol in water. The product melted at $189^{\circ}$, as did an authentic sample of D-galactose a-methylphenylhydrazone prepared in the same way. The mixed melting point was $188^{\circ}$.

The residue from the pentose fraction was chromatographed on paper. The pentose migrated like ribose in four different solvent systems, being clearly distinguished from arabinose and xylose. Direct comparison with lyxose was not made. A fast component was also present. A portion of the material was applied as a band to a sheet of Whatman no. 1 paper and the two components separated by ascending chromatography in $n$-butanol + ethanol + water. The bands were located by means of guide strips and eluted with water. The fast component migrated in the same position as glycerol in the three butanol-containing solvents. Deoxyribose ran very close to glycerol in these solvents, but was slightly faster than the unknown in $n$-butanol + pyridine + water and detectably slower in butanol + ethanol + water. The unknown gave a negative reaction with the diphenylamine reagent. It is unlikely that deoxyribose would survive the hydrolysis procedure. The unknown 
resembled glycerol in that the $\mathrm{AgNO}_{3}$ spots developed only when the papers were heated, and were grey-black. Reducing sugars give brown spots when the papers are exposed to $\mathrm{NH}_{3}$ vapour at room temperature, and these remain brownish-black for some time after heating.

\section{Isolation of the polysaccharide fraction}

Suspensions of washed organism in distilled water were subjected to three cycles of freezing and thawing, a mixture of solid $\mathrm{CO}_{2}$ and ethanol being used as the freezing bath. The frozen and thawed suspensions, containing 5-15 mg. dry weight/ml., were buffered to $\mathrm{pH} 8$ by the addition of 2-amino-2-hydroxymethylpropane$1: 3$ diol $\mathrm{HCl}$ (tris) to $0.04 \mathrm{M}$ and centrifuged at $26,000 \mathrm{~g}$ for $20 \mathrm{~min}$. in the cold. The supernatant fluid, which contained $50-80 \%$ of the RNA, and less than $5 \%$ of the galactose, was discarded, and the pellet (the 'cell-residue') was allowed to drain. Repeated washing of the cell-residue did not remove all the RNA, and little or none of the deoxyribonucleic acid (DNA) was removed under these conditions.

Extraction with aqueous phenol was carried out according to Westphal, Lüderitz \& Bister (1952). A suspension of the cell-residue in distilled water, containing 2-5 mg total carbohydrate/ml., was heated with an equal volume of a phenol + water mixture $(1: 1)$ at $65^{\circ}-70^{\circ}$ for $45 \mathrm{~min}$. The mixture was stirred vigorously during this period. After cooling in ice-water the phases were separated by centrifugation and the lower (phenol) layer was re-extracted once with a small volume of water at $65^{\circ}-70^{\circ}$. The pooled aqueous layers were dialysed against distilled water to remove phenol.

Table 2. Ultracentrifugation of dialysed aqueous phase from phenol extraction of Mycoplasma mycoides cell-residue

$\begin{array}{lccc} & \overbrace{\begin{array}{c}\text { Galactose } \\ (\mathbf{m g})\end{array}}^{\text {Total carbohydrate }} & \begin{array}{c}\text { Recovery } \\ (\%)\end{array} & \begin{array}{c}\text { Galactose } \\ \left(\mathbf{e}_{\mathbf{2 6 0}} / \mathbf{m g} .\right)\end{array} \\ & \mathbf{1 3 \cdot 2} & 100 & \mathbf{5 \cdot 6} \\ \text { Before centrifugation } & \mathbf{6 . 4} & \mathbf{4 9} & \mathbf{1 \cdot 4} \\ \text { After 2 centrifugations } & \mathbf{5 \cdot 7} & \mathbf{4 8} & \mathbf{0 \cdot 2 3} \\ \text { After 3 centrifugations } & \mathbf{4 \cdot 1} & \mathbf{3 1} & \mathbf{0 . 0 8}\end{array}$

Recovery of total carbohydrate for the phenol extraction step was $65-85 \%$. The dialysed aqueous layers contained RNA. Attempts to remove this by treatment with charcoal, RNase or $\mathrm{Mn}^{++}$salts were unsuccessful. Similar difficulties were encountered by Westphal, Lüderitz, Eichenberger \& Keiderling (1952), who found that the lipopolysaccharide of Escherichia coli could be separated from contaminating nucleic acid by differential ultracentrifugation. The polysaccharide in our preparations also sedimented more rapidly than the nucleic acid. Solutions, containing $0.5-1.5 \mathrm{mg}$. total carbohydrate $/ \mathrm{ml}$. in $0.1 \mathrm{M}$-sodium acetate $(\mathrm{pH} 8$ ), were centrifuged at $105,000 \mathrm{~g}$ for $4 \mathrm{hr}$. The tube contents were separated carefully by using a teat-pipette. In the most successful runs, $80-90 \%$ of the total carbohydrate was recovered in the fraction at the bottom of the tubes, and a sixfold purification, relative to nucleic acid, was achieved. Recovery and purification were often much 
lower than this, and repeated centrifugations were needed. Table 2 shows the course of a typical purification.

Preparations made in this way yielded $c .85 \%$ of the dry weight as reducing sugar after hydrolysis in $0.5 \mathrm{~N}-\mathrm{H}_{2} \mathrm{SO}_{4}$ for $2 \mathrm{hr}$. at $100^{\circ}$. The $\mathrm{P}$ content was less than $0 \cdot 1 \%$, but small and variable amounts of $\mathrm{N}(0 \cdot 3-0 \cdot 8 \%)$ suggested contamination with non-carbohydrate material. Because of this, and since the overall yields were low, a more efficient procedure was sought. It was found that the anion-exchanger Dowex 1 ( $2 \%$ cross-linked, analytical grade resin), in the chloride form, retained the RNA very much more strongly than the polysaccharide. The method, which gave good yields of a product of very low nucleic acid content, was applied to several larger-scale preparations. The dialysed aqueous layers from the phenol extraction step were passed through columns of the resin (200-400 mesh) until the desired purity was obtained. The amount of resin required depended on the nucleic acid content of the solution, and was determined empirically in small-scale tests. Details of two preparations are shown in Table 3. There was some retention of the polysaccharide on the resin and excess of the latter reduced the yield correspondingly. The final column effluents were concentrated on a rotary evaporator, centrifuged to remove dust particles and dialysed exhaustively against distilled water in the cold.

Table 3. Purification of Mycoplasma mycoides galactan by ion-exchange

\begin{tabular}{|c|c|c|c|}
\hline & \multicolumn{2}{|c|}{ Total carbohydrate } & \multirow[b]{2}{*}{$\begin{array}{l}\text { Galactose } \\
\left(e_{260 / \text { mg. }}\right)\end{array}$} \\
\hline & $\begin{array}{l}\text { Galactose } \\
\text { (mg.) }\end{array}$ & $\begin{array}{c}\text { Recovery } \\
(\%)\end{array}$ & \\
\hline \multicolumn{4}{|c|}{ Preparation L 1} \\
\hline Dialysed extract & 125 & 100 & $9 \cdot 0$ \\
\hline $\begin{array}{l}\text { Effluent from column } 1 \\
(20 \mathrm{~g} . \text { moist resin })\end{array}$ & 107 & 86 & $4 \cdot 4$ \\
\hline $\begin{array}{l}\text { Effluent from column } 2 \\
(40 \mathrm{~g} \text {. moist resin) }\end{array}$ & 99 & 79 & 0.04 \\
\hline \multicolumn{4}{|c|}{ Preparation L4 } \\
\hline Dialysed extract & 131 & 100 & $\mathbf{3} \cdot \mathbf{0}$ \\
\hline $\begin{array}{l}\text { Effluent from column } 1 \\
\text { (10 g. moist resin) }\end{array}$ & 121 & 92 & $1 \cdot 2$ \\
\hline $\begin{array}{l}\text { Effluent from column } 2 \\
(7 \mathrm{~g} . \text { moist resin) }\end{array}$ & 114 & 87 & 0.07 \\
\hline
\end{tabular}

\section{Properties of the polysaccharide fraction}

Because light-scattering by the somewhat opalescent solutions contributed to the observed optical densities at $260 \mathrm{~m} \mu$, the amount of nucleic acid remaining in the final fractions was not determined precisely; it was certainly less than $0.5 \%$. Preparations purified by ultracentrifugation contained rather more $\mathbf{N}$, and yielded slightly less reducing sugar on hydrolysis (Table 4), than did those which had been passed through the ion-exchange columns. No other differences were observed. All preparations showed comparable activity in the haemagglutination system (Cottew, 1960).

It is possible that some fractionation of the polysaccharide occurred during purification by both methods. Examination of preparation L5 (Table 4) in the 
analytical ultracentrifuge revealed the presence of a small amount of slowly sedimenting material (c. 2S) in addition to the principal boundary. The latter was hypersharp at $0.96 \%(\mathrm{w} / \mathrm{v})$ concentration, whether centrifugation was carried out in water or in $0.2 \mathrm{M}-\mathrm{NaCl}$. Dilution to $0 \cdot 24 \%(\mathrm{w} / \mathrm{v})$ increased the sedimentation constant of the main boundary, which remained markedly asymmetrical, to $19 \mathrm{~S}$ or about twice the value found at the higher concentration. No conclusions can be drawn concerning the homogeneity of the material composing the main peak. It was shown that the serologically active material in preparation L3 moved as a single band on paper electrophoresis over the range pH 4-11 (Buttery, 1959). No further tests of homogeneity were performed.

Table 4. Composition of Mycoplasma mycoides galactan

\begin{tabular}{|c|c|c|c|c|c|}
\hline \multicolumn{2}{|c|}{ Preparation } & $\mathbf{N}(\%)$ & $\mathbf{P}(\%)$ & Reducing sugar* $(\%)$ & $\operatorname{Ash}(\%)$ \\
\hline S2 & $\mathbf{U} \dagger$ & $0 \cdot 3$ & $<0 \cdot \mathbf{1}$ & $86\left(0.5 \mathrm{~N}-\mathrm{H}_{2} \mathrm{SO}_{4}, 2 \mathrm{hr}.\right)$ & - \\
\hline S3 & $\mathbf{U}^{\prime}$ & 0.5 & $<0.1$ & $83\left(0.5 \mathrm{~N}-\mathrm{H}_{2} \mathrm{SO}_{4}, 2 \mathrm{hr}.\right)$ & c. 3 \\
\hline $\mathbf{X}_{1}$ & $\mathbf{U}$ & $0 \cdot 4$ & $<0.1$ & $-\quad-$ & - \\
\hline L1 & $\mathbf{I} \dagger$ & $0 \cdot 15$ & - & $89\left(0.5 \mathrm{~N}-\mathrm{H}_{2} \mathrm{SO}_{4}, 2 \mathrm{hr}.\right)$ & 2 \\
\hline L3 & I & - & - & 88 (0.1 N-HCl, $1.5 \mathrm{hr})$. & - \\
\hline L4 & $\mathbf{I}$ & $<0 \cdot 1$ & $<0.1$ & $91(0.1 \mathrm{~N}-\mathrm{HCl}, 1 \mathrm{hr})$. & - \\
\hline L 5 & I & $0 \cdot 16$ & 0.06 & $89\left(0 \cdot 1 \mathrm{~N}-\mathrm{H}_{2} \mathrm{SO}_{4}, 2 \mathrm{hr}.\right)$ & $<1$ \\
\hline
\end{tabular}

* Determined by the Somogyi (1952) colorimetric method with D-galactose as the standard, calculated as anhydrohexose. Hydrolysis conditions shown in parentheses.

$\dagger U=$ purified by ultracentrifugation, $I=$ purified by ion-exchange.

Elementary analysis of preparation $\mathrm{L} 1$ was carried out by the Australian Microanalytical Service, C.S.I.R.O. Found: C44.09, $\mathrm{H} \mathrm{6.31}$, ash 1.99. $\mathrm{C}_{6} \mathrm{H}_{10} \mathrm{O}_{5}$ requires $\mathrm{C} 44 \cdot 44, \mathrm{H} 6 \cdot 22$. In no case did the yield of reducing sugar on hydrolysis approach the theoretical value for a simple polysaccharide. No sugar other than galactose was detected on paper chromatograms. No heptose was detected by the cysteine- $\mathrm{H}_{2} \mathrm{SO}_{4}$ reaction (Dische, 1953); the spectrum of the reaction product closely resembled that given by an equivalent amount of galactose. 3,6-Anhydrogalactose, if present, would yield 5-hydroxy-2-furaldehyde when heated in acid. No trace of this compound, which has an absorption spectrum with peaks at 228 and $285 \mathrm{~m} \mu$ (O'Neill, 1955), was detected in neutralized hydrolysates.

Acid-lability. The polysaccharide is very readily hydrolysed by acid. Table 5 shows the times required to obtain half the maximum yield of reducing sugar under various conditions. Data for inulin and lactose are included for comparison.

Periodate oxidation. Table 6 shows the course of periodate consumption by the polysaccharide. Samples of the reaction mixtures were treated with ethyleneglycol to remove unreacted periodate, reduced with sodium borohydride and dialysed against distilled water. The products were hydrolysed in $0.5 \mathrm{~N}-\mathrm{HCl}$ for $2 \mathrm{hr}$. at $100^{\circ}$. After removal of $\mathrm{HCl}$ by repeated evaporation, the hydrolysates were chromatographed in $n$-butanol + pyridine + water and in isopropanol + water. Authentic samples of D-galactose, I-threitol, L-arabinose, dulcitol, glycerol and ethylene glycol were run as markers. Spots corresponding in position to galactose, threitol and glycerol appeared in all the experimental samples when the papers were developed with the silver nitrate reagent. Material which had been oxidized for $1 \mathrm{hr}$. gave galactose as the major spot. After $60 \mathrm{hr}$. or longer, threitol was the most 
Table 5. Half-times for acid hydrolysis of Mycoplasma mycoides galactan

$\begin{array}{lccc} & \text { Acid } & \text { Temperature } & t_{1} \text { (min.) } \\ \text { Preparation L } 1 & 0.5-\mathrm{N}_{\mathbf{2}} \mathrm{H}_{2} \mathrm{SO}_{4} & 74 & 42 \\ & & 100 & 3.5 \\ & 0.01 \mathrm{~N}-\mathrm{H}_{2} \mathrm{SO}_{4} & 100 & 128 \\ \text { Inulin } & 0.01 \mathrm{~N}-\mathrm{HCl} & 100 & 120 \\ \text { Lactose } & 0.01 \mathrm{~N}-\mathrm{HCl} & 100 & \text { c. } 1 \\ & 0.01 \mathrm{~N}-\mathrm{HCl} & 100 & \text { c. } 3 \times 10^{3}\end{array}$

$t_{\frac{1}{2}}=$ time to attain half the maximal yield of reducing sugar.

abundant product. A rough visual comparison with mixtures of known composition indicated the presence of more than ten times as much threitol as of galactose or glycerol. In view of a recent report that glycerol may be lost during evaporation of solutions containing $\mathrm{HCl}$ (Hanahan \& Olley, 1958), it is possible that a larger proportion of glycerol was formed.

Table 6. Periodate oxidation of Mycoplasma mycoides polysaccharide.

The reaction mixture contained $2.5 \mathrm{mg}$ polysaccharide preparation $\mathrm{L} / \mathrm{4} / \mathrm{ml}$. and sodium metaperiodate at an initial concentration of $0.03 \mathrm{M}$. Temperature: $5^{\circ}, \mathrm{pH}$ c. 5 .

$\begin{array}{ccc}\begin{array}{c}\text { Experiment } \\ \text { no. }\end{array} & \text { Time } & \begin{array}{c}\text { Mole NaIO } \\ \text { consumed } / \text { mole } \\ \text { galactose }\end{array} \\ 1 & 13 \mathrm{~min} . & 0.12 \\ & 42 \mathrm{hr} . & 1.03 \\ 73 \mathrm{hr} . & 1.05 \\ 2 & 140 \mathrm{hr} . & 1.07 \\ & 35 \mathrm{~min} . & 0.13 \\ 18 \mathrm{hr} . & 0.92 \\ & 46 \mathrm{hr} . & 1.04 \\ & 120 \mathrm{hr} . & 1.08\end{array}$

The results are consistent with a structure composed mainly of galactopyranose units linked through $\mathrm{C} 4$ or of galactofuranose units linked through $\mathrm{C} 5$ or $\mathrm{C} 6$. The acid-lability of the material was consistent with the furanose structure, which has been assigned to galactocarolose, an acid-labile galactan formed by Penicillium charlesii G. Smith (Haworth, Raistrick \& Stacey, 1937). The terminal non-reducing end-groups of galactocarolose undergo rapid oxidation by periodate, with the release of formaldehyde from the primary alcohol group (O'Dea, 1953). The production of formaldehyde during oxidation of the Mycoplasma mycoides galactan was therefore studied. The reaction mixture contained $1.07 \mathrm{mg}$. preparation $\mathrm{L} 1 / \mathrm{ml} ., 0 \cdot 01 \mathrm{M}$-sodium metaperiodate and $0.05 \mathrm{M}$-sodium acetate buffer ( $\mathrm{pH} 3$ ). A slow release of formaldehyde was observed, amounting to less than 1 mole/100 mole galactose during $24 \mathrm{hr}$. This was probably not due to oxidation of primary alcohol groups. It was concluded that the galactan contains few, if any, unsubstituted galactofuranosyl end-groups.

Infra-red spectrum. The infra-red spectrum of the Mycoplasma mycoides galactan was very poorly defined, but broad bands were present near 870 and $805 \mathrm{~cm}^{-1}$. A sample of methyl $\beta$-galactofuranoside showed a rather broad band near $870 \mathrm{~cm}^{-1}$, possibly arising from vibrations of types B and C. (Barker \& Stephens, 1954) and another broad band near $805 \mathrm{~cm}^{-1}$, probably arising from their type $\mathrm{D}$ vibration. 
In the spectrum of methyl $\beta$-galactopyranoside, bands were observed near 887, 868 and $782 \mathrm{~cm}^{-1}$ as reported by Barker, Bourne, Stacey \& Whiffen (1954), but there was no band in the vicinity of $805 \mathrm{~cm}^{-1}$. The presence of a band at this latter frequency in the spectrum of the galactan is therefore not inconsistent with a furanose structure.

Evidence for a lipid component. It was noticed that the solutions became turbid during the early stages of acid hydrolysis and tended to clear on prolonged heating. This behaviour was consistent with the presence of a lipid component. A sample (10 mg.) of preparation L4 was hydrolysed for $8 \mathrm{hr}$. at $100^{\circ}$ with $5 \mathrm{ml} .5 \mathrm{~N}-\mathrm{HCl}$. The cooled solution was extracted three times with $10 \mathrm{ml}$. portions of ether. The ethereal extracts were dried over $\mathrm{Na}_{2} \mathrm{SO}_{4}$ and evaporated to dryness. The residue was dissolved in benzene for reversed-phase paper chromatography. No unsaturated acids were detected, but the copper reagent revealed two distinct bands corresponding in position to palmitic and stearic acid markers. The band which migrated like palmitic was the more intense of the two. The aqueous phase, after extraction of the fatty acids, was examined for the presence of ninhydrin-reactive compounds. No spots were detected on paper chromatograms; $0 \cdot 2 \%$ of an $\alpha$-amino acid would have been readily detected.

Isolation of a lipid fraction. A sample (19.2 mg.) of preparation $\mathrm{L} 4$ was heated at $100^{\circ}$ with $1.5 \mathrm{ml} .0 \cdot 1 \mathrm{~N}-\mathrm{HCl}$ under nitrogen. The solution became markedly turbid within $10 \mathrm{~min}$. After $1 \mathrm{hr}$. the mixture was cooled in ice and centrifuged at $\mathbf{3 0 , 0 0 0} \mathrm{g}$ for $20 \mathrm{~min}$. A pale yellow pellicle formed at the surface and adhered to the walls of the tube. It was recovered as completely as possible on a small filter paper and washed with a small volume of $0.1 \mathrm{~N}-\mathrm{HCl}$ and then with distilled water. The paper was dried in vacuo at room temperature, and the lipid extracted therefrom with ether and chloroform. After evaporation of the solvents the residue was dried in vacuo over $\mathrm{P}_{2} \mathrm{O}_{5}$ at room temperature; $0.5 \mathrm{mg}$. was recovered $(c .2 .5 \%$ of the weight of the intact polysaccharide). No sterols were detected in the lipid fraction by the Liebermann-Burchard reaction (Stadtman, 1957), but the presence of esterified fatty acids was indicated by the reaction with hydroxylamine, $100 \mu \mathrm{g}$. of the material giving the same optical density at $520 \mathrm{~m} \mu$ as did $59 \mu \mathrm{g}$. of trimyristin. A sample of the lipid (0.25 mg.) was saponified by heating for $1 \mathrm{hr}$. with $1 \mathrm{ml}$. ethanolic $\mathrm{KOH}$ (Entenman, 1957) at $100^{\circ}$. The solution was acidified and the fatty acids extracted with ether for chromatography as described above. Bands corresponding to palmitic and stearic acids were again observed, the former being the more intense. The aqueous phase was deionized and chromatographed on paper in three different solvent systems, with glycerol and galactose as markers, the spots being revealed with the $\mathrm{AgNO}_{3}$ reagent. The experimental material gave spots which moved the same distance as glycerol in all cases; no hexose was detected.

The lipid fraction could not be separated from the polysaccharide by simple solvent extraction. Preparation L5 was extracted under reflux with ethanol, ether and chloroform in that order. A sample $(55.8 \mathrm{mg})$ of the dried material was then hydrolysed with $6 \cdot 3 \mathrm{ml} .0 \cdot 1 \mathrm{~N}-\mathrm{H}_{2} \mathrm{SO}_{4}$ under nitrogen at $100^{\circ}$ for $2 \mathrm{hr}$. The solution was cooled and extracted twice with $2 \mathrm{ml}$. portions of light petroleum (b.p. $55^{\circ}-60^{\circ}$ ), and three times with $2 \mathrm{ml}$. portions of chloroform. The pooled extracts were washed three times with $1 \mathrm{ml}$. portions of water and evaporated to dryness. The residue, dried to constant weight in vacuo over $\mathrm{P}_{2} \mathrm{O}_{5}$ at room temperature, weighed $2 \cdot 3 \mathrm{mg}$, 
representing $4 \cdot 1 \%$ of the dry weight of the intact preparation. It contained $0 \cdot 3 \%$ $\mathbf{P}$, that is $c .20 \%$ of the total $\mathbf{P}$ of the unhydrolysed material. Since some degradation probably occurred during hydrolysis, the total weight of lipid, and its $\mathbf{P}$ content, may be somewhat higher than these data indicate. However, it is clear that the lipid cannot contain more than $1.5 \% \mathrm{P}$.

Optical rotation. The intact polysaccharide showed a large negative rotation; $[\alpha]_{D}=-140^{\circ}\left( \pm 3^{\circ}\right)\left(c=1, \mathrm{H}_{2} \mathrm{O}\right)$, determined for preparation $\mathrm{L} 5$ after exhaustive solvent extraction. The equilibrium value after acid hydrolysis and removal of the lipid fraction, $[\alpha]_{D}=+80 \cdot 8^{\circ}\left( \pm 2 \cdot 4^{\circ}\right)\left(c=0 \cdot 4, \mathrm{H}_{2} \mathrm{O}\right)$, shows that at least $97 \%$ of the sugar was D-galactose (theory for $100 \%$ D-galactose $=+80 \cdot 5^{\circ}$ ).

Biological properties. The serological reactions of the material are described in detail by Cottew (1960). Precipitin and indirect haemagglutination reactions were obtained with specific antisera. No pretreatment of the polysaccharide was required for sensitization of sheep erythrocytes. Heating for $1 \mathrm{hr}$. at $56^{\circ}$ in $0 \cdot 25 \mathrm{~N}-\mathrm{NaOH}$ destroyed the capacity to sensitize erythrocytes, as well as the capacity to inhibit the agglutination of sensitized erythrocytes. This behaviour is in marked contrast to that reported for enterobacterial lipopolysaccharides. No significant temperature rise was observed following the injection of the Mycoplasma mycoides polysaccharide into rabbits at doses up to $1 \mu \mathrm{g} . / \mathrm{kg}$.

\section{DISCUSSION}

Further characterization of the lipid fraction and of the way in which it is linked to the carbohydrate moiety will probably require larger amounts of material than are at present available. In the absence of this information, and of data on the homogeneity of the product and the nature of the fraction (c. $5 \%)$ still unaccounted for, no definite structure can be assigned to the galactose polymer. The large negative rotation indicates the $\beta$-galactosyl configuration. The observed value is in fact more negative than any reported for galactans of known structure, being approached only by that for galactocarolose $\left([\alpha]_{D}=-84^{\circ}\right.$; Haworth et al. 1937). The Mycoplasma mycoides galactan is rather more stable to acid hydrolysis than galactocarolose, but more labile than varianose, a small polysaccharide composed mainly of - 1:4- $\beta$-galactopyranosyl units (Haworth, Raistrick \& Stacey, 1935). Another galactan thought to consist mainly of -1:4- $\beta$-D-galactopyranosyl units was isolated from the seeds of Strychnos nux-vomica by Andrews, Hough \& Jones (1954); this has $[\alpha]_{D}=+69^{\circ}$, and is much more stable to acid than is varianose. Since other features of the molecule may have a marked influence on hydrolysis rates, no firm conclusions concerning the ring form can be drawn from these data. Moreover, the acid-stability of the methyl galactoseptanosides is similar to that of the furanosides (Micheel \& Suckfüll, 1933). Structures containing the sevenmembered ring would also be consistent with the periodate data for the $M$. mycoides galactan.

The Mycoplasma mycoides galactan has little in common with the lipopolysaccharides of typical Gram-negative bacteria. The latter are characterized by a relatively high content of $\mathbf{N}, \mathbf{P}$ and lipid and are composed of a number of different sugars and hexosamines. Apart from the observation that it inhibits the agglutination of formalized suspensions, we have no evidence that the galactan forms part of the surface structure of $M$. mycoides. The amounts of galactose present in the 
organisms would be sufficient for such a role. Experiments to determine the part played by the lipid and carbohydrate components in the serological reactions are in progress.

We wish to thank Mr G. S. Cottew for carrying out serological tests, Mr J. M. Gillespie for the analytical ultracentrifugations, Mr H. G. Higgins for the infra-red spectra and their interpretation, and Mr N. M. Semple for pyrogen tests. Our thanks are also due to Dr A. W. Turner and Dr A. W. Rodwell for many valuable discussions.

\section{REFERENCES}

ANDrews, P., Hough, L. \& Jones, J. K. N. (1954). The galactan of Strychnos nux-vomica seeds. J. chem. Soc. 806 .

Ballance, P. E. \& Crombie, W. M. (1958). Paper chromatography of saturated and unsaturated fatty acids. Biochem. J. 69, 632.

Barker, S. A. \& Stephens, R. (1954). Infra-red spectra of carbohydrates. Part IV. Characterisation of furanose derivatives. J. chem. Soc. p. 4550.

Barker, S. A., Bourne, E. J., Stacey, M. \& Whiffen, D. H. (1954). Infra-red spectra of carbohydrates. Part I. Some derivatives of D-glucopyranose. J. chem. Soc. 171.

Bartlett, G. R. (1959). Phosphorus assay in column chromatography. J. biol. Chem. 234, 466 .

Buchanan, J. G., Dekker, C. A. \& Long, A. G. (1950). The detection of glycosides and non-reducing carbohydrate derivatives in paper partition chromatography. J. chem. Soc. p. 3162.

ButTERy, S. (1959). Detection of antigens as specific precipitates on paper electrophoresis strips. Nature, Lond. 183, 686.

Chen, P. S. Jr., Toribara, T. Y. \& Warner, H. (1956). Microdetermination of phosphorus. Anal. Chem. 28, 1756.

Conway, E. J. (1947). Microdiffusion Analysis and Volumetric Error. Revised ed., p. 132. London: Crosby Lockwood.

Cоттеw, G. S. (1960). Indirect haemagglutination and haemagglutination inhibition with Mycoplasma mycoides. Aust. vet. J. 36, 54.

Cummins, C. S. \& Harris, H. (1956). The chemical composition of the cell wall in some Gram-positive bacteria and its possible value as a taxonomic character. J. gen. Microbiol. 14, 583.

DEDONDER, R. (1952). Sugars and related compounds. Bull. Soc. chim. Fr. p. 874.

Dische, Z. (1947). A new specific color reaction of hexuronic acids. J. biol. Chem. 167, 189.

Dische, Z. (1953). Qualitative and quantitative colorimetric determination of heptoses. J. biol. Chem. 204, 983.

Dische, Z. (1955). Color reactions of nucleic acid components. In The Nucleic Acids, ed. E. Chargaff \& J. N. Davidson, r, p. 285. New York: Academic Press Inc.

Entenman, C. (1957). Preparation and determination of higher fatty acids. In Methods in Enzymology, ed. S. P. Colowick \& N. O. Kaplan, III, p. 317. New York: Academic Press Inc.

GotTschalk, A. \& ADA, G. L. (1956). The separation and quantitative determination of the component sugars of mucoproteins. Biochem. J. 62, 681 .

Hanahan, D. J. \& Olley, J. N. (1958). Chemical nature of monophosphoinositides. J. biol. Chem. $231,813$.

Haworth, W. N., Raistrick, H. \& Stacey, M. (1935). The molecular structure of varianose produced from glucose by Penicillium varians G. Smith. Biochem. J. 29, 2668.

Haworth, W. N., Raistrick, H. \& STACey, M. (1937). The molecular structure of galactocarolose produced from glucose by Penicillium charlesii G. Smith. Biochem. J. 31, 640.

Heyrovsky, A. (1956). A new detection method for paper chromatography of sugars. Biochem. biophys. Acta, 21, 180. 
Hough, L., Jones, J. K. N. \& Wadman, W. H. (1949). The separation of the sugars and their methylated derivatives on columns of powdered cellulose. J. chem. Soc. p. 2511.

KANDLER, O. \& Zehender, C. (1957). Über das Vorkommen von $\alpha, \epsilon$-Diaminopimelinsäure bei verschiedenen L-Phasentypen von Proteus vulgaris und bei den pleuropneumonie-ähnlichen Organismen. Z. Naturf. $12 b, 725$.

Kurotchkin, T. J. (1937). Specific carbohydrate from Asterococcus mycoides for serological tests of bovine pleuropneumonia. Proc. Soc. exp. Biol., N.Y. 37, 21.

Mrcheel, F. \& Suckfüll, F. (1933). Die Hydrolyse des $\alpha$-Methyl-galakto-septanosids. Ber. dtsch. chem. Ges. 66, 1957.

Militzer, W. E. (1946). The orcinol reagent. Arch. Biochem. 9, 85.

Mitcheld, P. (1949). A new technique for stirred aerated culture. Nature, Lond. 164, 846.

NASH, T. (1953). The colorimetric estimation of formaldehyde by means of the Hantzsh reaction. Biochem. J. 55, 416.

Nowotny, A., LüDeritz, O. \& Westrhal, O. (1958). Rudfilter-Chromatographie langkettiger Fettsäuren bei der Analyse bakterieller Lipopolysaccharide. Biochem. Z. 330, 47.

O'DEa, J. F. (1953). Production of formaldehyde during the oxidation of carbohydrates with periodate. Chem. Ind. 1338.

O'Dea, J. F. \& Gibbons, R. A. (1953). The estimation of small amounts of formaldehyde liberated during the oxidation of carbohydrates and other substances with periodate. Biochem. J. 55, 580.

O'Neill, A. N. (1955). 3,6-anhydro-D-galactose as a constituent of $\kappa$-carrageenin. J. Amer. chem. Soc. 77, 2837.

Placketr, P. (1959). On the probable absence of mucocomplex from Mycoplasma mycoides. Biochem. biophys. Acta, 35, 260.

Rodwell, A. W. \& Rodwell, E. S. (1954). The breakdown of carbohydrates by Asterococcus mycoides, the organism of bovine pleuropneumonia. Aust. J. biol. Sci. 7, 18.

Somogyi, M. (1952). Notes on sugar determination. J. biol. Chem. 195, 19.

Stadtman, T. C. (1957). Preparation and assay of cholesterol and ergosterol. In Methods in Enzymology, ed. S. P. Colowick \& N. O. Kaplan, III, p. 392. New York: Academic Press Inc.

Stern, I. \& Shapiro, B. (1953). A rapid and simple method for the determination of esterified fatty acids and for total fatty acids in blood. J. clin. Path. 6, 158.

Trevelyan, W. E. \& Harrison, J. S. (1952). Studies on yeast metabolism. I. Fractionation and microdetermination of cell carbohydrates. Biochem. J. 50, 298.

'Turner, A. W., CAmpbell, A. D. \& Dick, A. T. (1935). Recent work on pleuropneumonia contagiosa boum in North Queensland. Aust. vet. J. 11, 63.

VASSEUR, E. (1948). A spectrophotometric study on the orcinol reaction with carbohydrates. Acta chem. scand. 2, 693.

Westphal, O., LüDeritz, O. \& Bister, F. (1952). Über die Extraktion von Bakterien mit Phenol/Wasser. Z. Naturf. $7 b, 148$.

Westphal, O., Lüderitz, O., Eichenberger, E. \& Keidering, W. (1952). Über bakterielle Reizstoffe I. Mitt.: Reindarstellung eines Polysaccharid-Pyrogens aus Bacterium coli. Z. Naturf. 7 b, 536. 